\title{
Can Intellectual Capital of SMEs Help in Their Sustainability Efforts
}

\author{
Chaudhry Shoaib Akhtar (Corresponding Author)
}

Faculty of Management, Universiti Teknologi Malaysia

Johor Bahru, 81310, Johor, Malaysia

Tel: 60-13-741-1139_E-mail: csakhtar@gmail.com

\author{
Kamariah Ismail \\ Faculty of Management, Universiti Teknologi Malaysia \\ Johor Bahru, 81310, Johor, Malaysia \\ E-mail:m-maria@utm.my
}

\author{
M. A. Ndaliman \\ Faculty of Management, Universiti Teknologi Malaysia \\ Johor Bahru, 81310, Johor, Malaysia \\ E-mail: ndaliman2000@yahoo.com
}

Jawad Hussain

Faculty of Management, Universiti Teknologi Malaysia

Johor Bahru, 81310, Johor, Malaysia

E-mail: jawadhussain79@gmail.com

Maqsood Haider

Faculty of Management, Universiti Teknologi Malaysia

Johor Bahru, 81310, Johor, Malaysia

E-mail: maqsood_afridi2004@yahoo.com 


\title{
Macrothink
}

Journal of Management Research

ISSN 1941-899X

2015, Vol. 7, No. 2

Received: August 11, 2014 Accepted: November 17, 2014 Published: February 1, 2015

doi:10.5296/jmr.v7i2.6930

URL: http://dx.doi.org/10.5296/jmr.v7i2.6930

\begin{abstract}
Small and medium enterprises due to their smaller size and resources face numerous challenges to sustain themselves. In the face of mounting pressures from the competitors, SMEs need to position themselves in such a way so as to cater for the changing customer needs and expectations of their customers. To achieve this, developing the internal knowledge and knowing capabilities becomes imperative. The present study is an attempt to investigate the role of intellectual capital towards sustainability. Sample consisted of SMEs selected from the database of Federation of Malaysian Manufacturers. Self-administered questionnaires were distributed to 335 respondents with a response rate of $51 \%$. The results of the study indicate that intellectual capital is having a significant relationship as well as influence on sustainability of SMEs. Further, multiple regression results reveal that knowledge and innovativeness dimensions of intellectual capital are more influential in creating sustainability for small enterprises. However, employee competences, intellectual agility and skills have been found to insignificant in Malaysian context. The results reveal that if intellectual capital of the employees is not optimally harnessed, it would lead to failure. The study is significant not only for the owners/managers of SMEs but also for the policy makers. Future directions are also provided for researchers interested in the area.
\end{abstract}

Keywords: Intellectual Capital, Sustainability, Knowledge, Competence, Innovativeness, Skills, SMEs, Malaysia. 


\section{Introduction}

Modern day business environment is not only complex but also full of challenges. The move towards knowledge economy has resulted in numerous challenges, the foremost being remaining competitive. Organizations of all sizes face this dilemma and especially small and medium enterprises (SMEs) are more vulnerable to external economic shocks as compared to larger organizations in this competitive knowledge oriented business environment that results in their failure (SMEAR, 2012). Large number of studies indicate that majority of the small firms disappear within the first five years of their operation (Cook, Campbell \& Kelly, 2012; Kuratko \& Hodgetts, 2004; Shane, 2012; Zimmerer, Searborough \& Wilson, 2008). Business failure not only affects the firms but also national economies by affecting the employment rates and contribution to the national income (Fritsch \& Noseleit, 2013). Researchers argue that despite the potential of adding jobs faster than bigger firms, smaller firms also eliminate them faster with each business failure (Haltiwanger, Jarmin, \& Miranda, 2013). Thus, survival and sustainability of the small firms is crucial for the overall economic development of the country.

Malaysia being fast developing country relies heavily on SMEs for economic development. Their role has also been recognized by Malaysian government due to their numbers, size, and nature of operations for economic growth (Aris, 2006). SMEs have been the highest employment generator in Malaysia with approximately $60 \%$ of total labor force being employed by them (SMEAR, 2012). Despite the efforts of the Malaysian government to develop SMEs in the country, the overall success rate stands at 58\% (SMECorp, 2013) indicating a failure rate of $42 \%$. This is mainly due to the fact that majority of the people employed by SMEs are non-skilled and the skilled workforce needed for innovation and expansion was in dearth (SMEAR, 2012). According to Rosli (2012) Malaysian SMEs emphasize far less on innovation and global orientation as compared to cost minimization, product differentiation and market niche to compete in the market place. They are also less inclined to invest in internet and research and development (R\&D), which reflects badly on their effectiveness. Investment in R\&D requires highly skilled experts that provide the much needed knowledge and innovation for SMEs sustainability. The existence of competition makes human resource, a survival and existence key, capable of providing hedge to SMEs in term of profit and sustainability. It is a vital tool capable of reviving a dying company as well as provide a strong base for sustainability to healthy ones (Obasan, 2012).

Sustainability of an organization in this globalized competitive business environment has taken a paramount importance. Across the world, business organizations especially small and medium enterprises are working to attain competitive advantage and sustainability through developing skilled human resources as well as linkages that would help them achieve competitiveness. The concept of sustainability is still a new concept in among Malaysian organizations and many industries and businesses do not understand the benefits of sustainable practices (Goh, Seow \& Goh, 2013; Yacob, Aziz, Makmor \& Zin, 2013). In a study of SMEs in Malaysia, Koe and Majid (2013) and Yacob, et al., (2013) found that though SMEs were aware of sustainable practices and had plans for implementing them as well, but the actual adoption of sustainable practices were less embracing. Research 
highlights that Malaysian SMEs face many challenges in a globalized world such as lack of financing, low productivity, lack of managerial capabilities, low skilled workforce, inability to adopt technology, lack of information on potential markets and customers and global competition (Hashim, 2012; Hoq, Ha \& Said, 2009; Kee-Luen, et al 2013; Saleh, Caputi \& Harvie, 2008).

UNESCAP (2013) highlights that there is a need of high technology skills, if Malaysia wants to move from middle income bracket to high income by 2020. The report further highlights that the local organizations employ less skilled workers as compared to foreign owned Malaysian organizations. Furthermore, Malaysian firms lack absorptive capacity to upgrade manufacturing activities from low to high value added activities. Due to lack of proper skills among the local population, local companies have not been able to fully benefit from knowledge or technology spillovers from foreign companies. Aldaba and Aldaba (2010) have highlighted that SME manufacturing sector can benefit hugely from skilled human resources, industrial and technology upgrading or development of technological capabilities and specialized skills of firms, improved linkages between local firms through information exchange, capacity building and adequate funding for the competitiveness and linkages program by the government. Highly skilled and educated labor force would be in a better position to adopt new technologies as compared to low skilled workforce (UNESCAP, 2013). The absorptive capacity of local companies is also largely determined by the research \& development capacity of the firm and the level of education among the employees (Lipsey \& Sjoholm, 2005; Suyanto \& Block, 2009). Thus, the importance of SMEs cannot be underestimated and for them to develop and sustain for longer period of time they need stronger intellectual capital. The present study is an attempt to investigate the role of intellectual capital towards sustainability of small and medium enterprises in Malaysia.

\section{Literature Review}

\subsection{Sustainability}

The concept of sustainability has been associated with Wes Jackson's work on agriculture (Jackson, 1980) which was later on taken up by Brundtland Commission Report. The report defined sustainability in terms of development of the human ecology as 'development that meets the needs of the present generation without compromising the ability of future generations to meet their own needs' (WECD, 1987). In terms of business organizations, sustainability refers to as the meeting the needs of an organization's direct and indirect stakeholders such as shareholders, employees, clients, communities etc, without compromising its ability to meet the needs of future stakeholders as well. To attain this organizations have to maintain and grow their economic, social and environmental capital base while actively contributing to sustainability in the political domain (Dyllick \& Hockerts, 2002). The brundtland report also emphasized on the role of technologies and highlighted that developing countries need to work to develop their technological base for sustainable development. To develop the technological base, skilled and capable human resource is required. However, Malaysia, being a developing country falling in the middle income group lacks skilled workforce (Rosli, 2012; Martinez-Fernandaz \& Choi, 2013). This workforce is 
needed not only to drive the innovation but also is essential for growth of science and technology related industries.

From business perspective, sustainability connotes three dimensions: economic, social and environmental (Choi \& Ng, 2011; Leaniz \& Bosque, 2013; Sheth, et al. 2011). Sustainability is an approach, organizations around the world are increasingly adopting to conduct businesses, but the research highlights that majority of the organizations though appreciative of the sustainability practices are slow to adopt them (Leaniz \& Bosque, 2013). Out of three sustainability dimensions, literature has repeatedly focused on the environmental dimension because of the impact of rapid consumption on the environmental degradation and eco-system resource constraints (Choi \& Ng, 2011; Sheth, et al., 2011). The interrelationships between society, the environment and economic or industrial development are integral to the concept of sustainability (Hutchins \& Sutherland, 2008).

Economic dimension of sustainability refers to the organizational capability to create value and enhance financial performance (Leaniz \& Bosque, 2013). With the increased international economic and financial crisis, governments and organizations are deeply concerned with the economic sustainability dimension due to fear of job losses and financial risks to various programs and projects undertaken by the governments and businesses (Choi $\& \mathrm{Ng}, 2011)$. Researchers have outlined two aspects of economic sustainability: cost reductions and economic interests of external stakeholders such as improvement in economic wellbeing and cost of living (Sheth, et al 2011). Leaniz and Bosque (2013) highlight that organizations involved in sharing of information with the stakeholders regarding their profits, achieving long term success, improving economic performance would help achieve economic sustainability.

Since publication of Brundtland Commission Report, the notion of environmental responsibility is becoming more pronounced. An environmentally responsible firm can be described as one which seeks to limit or prevent damage to existing natural environment (Schaper, 2002). According to Murphy, Poist and Braunschweig (1995) it is the practice of responding to environmental issues in a socially responsible manner; whilst Longenecker and Moore (2006) argue that it is the effort to protect and preserve the environment. Environmental responsibility within an organization can take the form of steps to reduce, recycle and reuse raw materials and waste materials; minimizing the impact of transportation, energy and water usage by organizations, donating or contributing to environmental groups; adoption of environmental policy (ISO standards) or reduction in pollution by the organization (Schaper, 2002). Sidek and Backhouse (2014) has pointed out that certain key elements such as attitude, awareness, characteristics, support etc of SMEs either compel or hinder their adoption of environmentally sustainable practices. In case of Malaysia, being a developing country environmental sustainability is still in its early stages. With government focusing on taking steps in environmentally sustainable practices for industries and businesses, issues have been reported in adopting such practices. In a study by Sidek and Backhouse (2014) found that family owned SMEs in Malaysia were more reluctant to change their management practices regarding adoption of environmentally sustainable practices as compared to modern SMEs. Furthermore, the authors also found that export oriented SMEs 
were more environmentally sustainable oriented as they had to comply with international standards and regulations for exporting their products as compared to SMEs that focused more on internal market.

The social dimension of sustainability relates to the societal issues and is concerned with the well-being of people and communities as a non-economic form of wealth (Choi \& $\mathrm{Ng}, 2011$ ). This dimension has gained popularity mainly due to the fact that people expect organizations to do more for social well-being of the communities in which they operate (Mohr \& Webb, 2005). Leaniz and Bosque (2013) are also of the view that organizations engaging in community welfare oriented programs such as solving social problems, collaborating in cultural and social events, committing to improving the welfare of communities would obtain competitive advantage. The social sustainability has not been well-defined in the literature and less focus has been paid on this dimension of sustainability. However, there are researches that have related social sustainability to legislative issues or human health and safety issues rather than cultural and ethical consequences of decisions (Hutchins \& Sutherland, 2008; Seuring \& Muller, 2008). Bramley and Power (2009) argue that social sustainability is social capital, social cohesion and social exclusion. His argument is based on literature that equates social sustainability as social development in attaining basic development issues like access to necessary goods and services and other higher order needs, which has also been highlighted in the Brundtland report. The report emphasizes that once people's basic needs are met can they begin to actively address other issues concerning environment etc.

\subsection{Intellectual Capital}

In this age of information and globalization, information is considered as a main input for all organizations whether big or small. This information is intangible in form and the real value lies in the skills and knowledge of people (Topal, Conkar \& Mustafa, 2008), which is the intellectual capital of the organizations. This intellectual capital with all its components is abstract in nature that provides competitive advantage to organizations against their rivals in the market place. It is a phenomenon like information that can only be observed (Topal, et al., 2008) and are mostly related to the skills, knowledge, innovativeness of employees etc. (Bontis, 2001).

According to Nahapiet and Ghoshal (1998) intellectual capital is the knowledge and knowing capability of a social collectivity. The social group exhibits two major forms of knowledge social explicit and social tacit which are collective in nature. According to McGrath and Sparks (2006) knowledge that forms intellectual capital can be viewed as two processes that is combination and exchange. Thus, intellectual capital is the combination of new and previous knowledge that were being held but not connected. Exchange is often the key facilitator of this combination and this can occur through networks alone (McGrath and Sparks, 2006). Similar views have also been expressed by Papagiannidis, Li, Etzkowitz and Clouser (2009) who links human capital a component of intellectual capital (Wall, et al. 2004) to social capital through networks. It is thus, the human potential possessed by an organization, which can be converted to intellectual assets (Bounfour \& Edvinsson, 2005; 
Grajkowska, 2011).

Dzinkowski (2000) has termed intellectual capital as fixed and flexible and input and output of a value creation process, that is, fixed as in patents and flexible as in human capabilities; whereas intellectual capital if seen in terms of input and output is knowledge converted into value. This value is created through the human assets employed by organizations. Edvinsson (1997) argues that human capital is volatile and cannot be owned but can only be traded to enhance performance of an organization, thus making it a strategic asset. Moore and Craig (2008) while discussing the strategic importance of IC highlight that the organizational management rarely treats IC as of strategic importance. Thus, there is a need to understand the strategic importance of IC by the decision makers for gaining leverage of such resources (Moore \& Craig, 2008).

\subsection{Hypotheses Development and Model of the Study}

Moore and Craig (2008) are of the opinion that the most important strategic business purpose of an organization is to attain the competitive positioning and its continuation. To achieve this, the top management of organizations is always trying to leverage the intangible assets to attain the sustainable competitive position in the market place. Similar arguments have also been proposed by Bartholomew (2008), who is of the opinion that organizations need to become better at acquiring and creating and utilizing the existing intellectual capital if they want to remain competitive. He further highlights that the role of knowledge especially tacit knowledge is of utmost importance if organizations need to be successful in the future.

As the world moves from information age to knowledge age, everything moves faster and gets intertwined with other people, societies and technologies. The explosion of information, communication, speed and networking has increased the state of complexity, which is characterized by Bennet and Bennet (2004) as increasing change, rising uncertainty, growing complexity and ubiquitous anxiety (CUCA). With the increased uncertainty in today's world, individuals need to be more flexible, adaptable and having larger perspectives to a problem solutions. Employees need to think for themselves, collaborate and study their environment in order to take right decisions and actions (Bennet and Bennet, 2010). As the environment changes, the competencies and capacities of today's worker need to be changed for ensuring flexibility, quick responsiveness, resilience, robustness and continuous learning for sustainability (Bennet and Bennet, 2010).

Hashim (2012) and Saleh, et al (2008) highlight that skills, knowledge, competencies of employees is of utmost importance for SMEs not only to acquire new technology and knowledge but also for their survival in this globalized world. Due to the limited capacities of SMEs they are less innovative as compared to their counterparts in other countries (Hashim, 2012). However, Kee-Luen et al. (2013) have found that Malaysian SMEs do put emphasis on internal learning and growth to achieve competitiveness. Furthermore, the knowledge, values, skills and experiences of employees have significant impacts on social and environmental sustainability of SMEs and this intellectual capital can be used to attain competitive advantage for promoting innovations regarding social and environmental practices and keeping themselves ahead of competitors (Loucks, et al. 2010). Thus, based on 
the discussion above, we hypothesize that

H1: There is a strong relationship between intellectual capital and its dimensions and organizational sustainability.

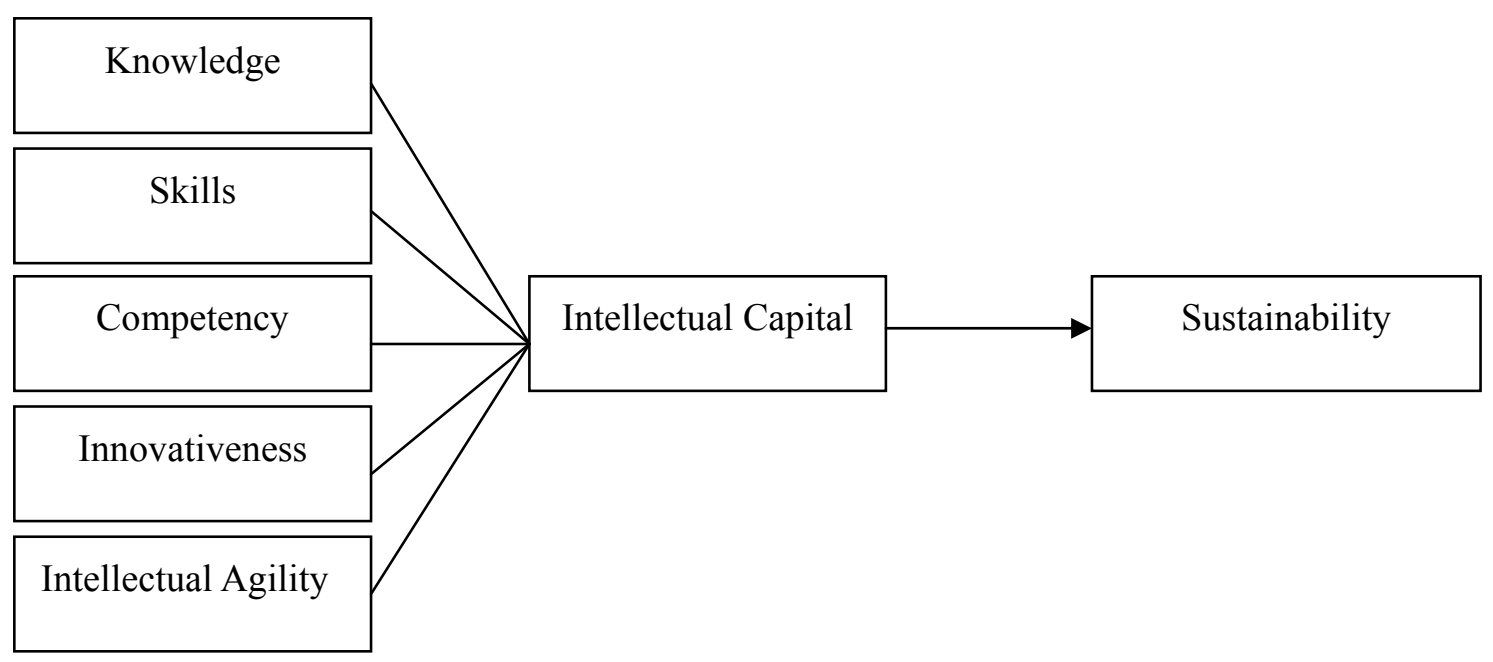

\section{Methodology}

The study was conducted to investigate the role of intellectual capital in the sustainability of SMEs. Using survey design self administered questionnaire (SAQ) were distributed to the sample. SMEs belonging to Federation of Malaysian Manufacturers (FMM) were considered as the population. In addition, micro-enterprises were not part of the study and were thus, excluded from the population frame. The sample was selected using systematic random sampling technique. The sample size for the study was 335, based on Krejcie and Morgan (1970) sampling size formula. For the unit of analysis, it was found appropriate to take the responses from the manager/owners of the SMEs or their proxies, if the owner/manager was not available.

The instrument for the study was developed after extensive literature review. The instrument consisted of 37 items comprising knowledge, skills, competency, intellectual agility and innovativeness dimensions of intellectual capital. The sustainability variable was measured using 41 items corresponding to the three dimensions of social, economic and environmental sustainability. The SAQ was mail delivered to the selected respondents. In addition, web based questionnaire was also distributed by sharing the link with the respondents through emails. After repeated requests via emails and also through telephonic conversations, a total of 171 usable questionnaires were collected, making a response rate of $51 \%$.

The instrument was subjected to exploratory factor analysis and reliability testing. The reliability of the instrument was found to be between 0.80-0.90 indicating that the instrument was reliable. Further, factor analysis results indicated the validity of the instrument. Validity was also established through extensive literature review. After establishing the validity and reliability of the instrument, the data was subjected to further statistical tests such as Pearson correlation and regression analysis. Before proceeding to regression analysis, assumptions 
related to regression were satisfied by the researchers.

The demographic profile of the respondents indicated that 41.2 percent of the SMEs were from manufacturing sector while 58.8 percent of the SMEs belonged to services sector. The employee category indicated that majority of the SMEs $(59.7 \%)$ had more than 5 and less than 30 employees; while 36.1 percent of SMEs had employees in the range of 30-74. Only 4.2 percent of SMEs had more than 75 and less than 200 employees. These employee categories corresponded to the new definition that has been adopted by Malaysia. The gender category indicated that majority of the owners/managers were male (62\%) and only 38 percent were females. The owners/managers were asked whether they provided any kind of training to their employees for building their skills and competencies. The results related to training indicated that majority of the owners/managers of SMEs (40.6\%) did not provide any kind of training to their employees. The remaining SMEs owners/managers indicated that they have been providing training in the form of short courses to enhance the skills and capabilities of their employees (35.3\%); while 17.6 percent of SMEs had provided higher education opportunities and only 6.4 percent had provided technical trainings to their employees.

\section{Results and Discussion}

Pearson correlation analysis was used to establish the relationship between intellectual capital (IC) and its dimensions and organizational sustainability. The result of correlation is shown in Table 1. The result indicates that intellectual capital and sustainability are strongly correlated with each other $(r=.663, p<0.01)$. Similarly, the correlation for the dimensions of IC indicates that all five dimensions have a strong and positive relationship with sustainability.

Table 1. Correlation Matrix

\begin{tabular}{|c|c|c|c|c|c|c|c|}
\hline & Sustainability & $\mathrm{IC}$ & Know & Innov & Comp & IA & Skill \\
\hline Sustainability & 1 & & & & & & \\
\hline Intellectual Capital & $.663^{* *}$ & 1 & & & & & \\
\hline Knowledge & $.667^{* *}$ & $.782^{* *}$ & 1 & & & & \\
\hline Innovativeness & $.569^{* *}$ & $.725^{* *}$ & $.549^{* *}$ & 1 & & & \\
\hline Competence & $.481^{* *}$ & $.797^{* *}$ & $.574^{* *}$ & $.363^{* *}$ & 1 & & \\
\hline Intellectual Agility & $.456^{* *}$ & $.835^{* *}$ & $.524^{* *}$ & $.417^{* *}$ & $.662^{* *}$ & 1 & \\
\hline Skill & $.446^{* *}$ & $.824^{* *}$ & $.525^{* *}$ & $.347^{* *}$ & $.688^{* *}$ & $.755^{* *}$ & 1 \\
\hline
\end{tabular}

The regression analysis was performed to check for the relationship between intellectual capital and sustainability and also to find out the most influential dimension of intellectual capital that influences sustainability. The results for regression analysis are shown in Table 2. 
Table 2. Regression Analysis

\begin{tabular}{|c|c|c|c|c|}
\hline Model & Summary & Beta & $\mathrm{t}$ & Sig. \\
\hline IC-Sustainability & $\begin{array}{l}\mathrm{R} .663 \\
\mathrm{R}^{2} .440 \\
\text { Adj. } \mathrm{R}^{2} .437 \\
\mathrm{~F} 145.084(\mathrm{p}=0.000)\end{array}$ & .770 & 12.045 & .000 \\
\hline Knowledge & \multirow{5}{*}{$\begin{array}{l}R .718 \\
R^{2} .516 \\
\text { Adj. } R^{2} .503 \\
\text { F } 38.619(p=0.000)\end{array}$} & .301 & 5.962 & .000 \\
\hline Innovativeness & & .483 & 4.386 & .000 \\
\hline Competence & & .188 & 1.097 & .274 \\
\hline Intellectual agility & & .096 & .276 & .783 \\
\hline skills & & .023 & .562 & .574 \\
\hline
\end{tabular}

The regression result for IC and sustainability indicate a strong relationship between the two variables $(\mathrm{R}=.663)$. The $\mathrm{R} 2$ indicates that $\mathrm{IC}$ is causing 44 percent variation in sustainability (R2 .440). The overall model for IC-Sustainability is fit as indicated by the F-statistic value. Further analysis indicates that IC has a strong influence on sustainability $(\beta=0.770, p<0.01)$. Similarly, multiple regression was applied to test the relationship and influence of dimensions of IC on sustainability. The result is shown in Table2. The multiple regression results indicate that Knowledge $(\beta=0.301, p<0.01)$ and Innovativeness of employee $(\beta=0.483, p<0.01)$ are having strong and statistically significant influence on sustainability. However, competence $(\beta=0.188, p>0.05)$, intellectual agility $(\beta=0.096, p>0.05)$ and skills of employees $(\beta=0.023, p>0.05)$ were found to have no significant influence on sustainability. Similarly, the result indicates that out of all five IC dimensions, innovativeness of employees has the highest impact on sustainability, which is followed by knowledge dimension of IC.

The results of the study are important from SMEs perspective. The results indicate that intellectual capital is one of the most important factors in attaining sustainability by SMEs. The results of the study are in line with the previous studies that indicate Intellectual capital to be one of the most valuable intangible resource for organizational growth in today's knowledge based economy (Karchegani, et al. 2012) and to attain competitive advantage (Aas \& Pedersen, 2011; Kramer, et al. 2011) through innovativeness of the employees (Spahic \& Huruz, 2012; Wang \& Wang, 2012) for increased performance as well as to attain sustainability (Karchegani, et al. 2013; Rosenbusch, et al., 2011). The present study do agree with Rosli (2012) who highlighted that Malaysian SMEs emphasize less on innovation and also spend less on R\&D. However, R\&D requires highly skilled employees. The results do indicate that Malaysian SMEs have less competent and agile workforce as indicated by the insignificant results for competence, intellectual agility and skills. Furthermore, Malaysian SMEs also do not provide training to their employees, which is essential for building up the skills and competencies of the employees especially in this knowledge economy. These training whether technical, higher education or short courses for enhancing skills are necessary to make employees more agile and adaptable to the external environment. This agility helps employees as well as owners/managers of the small enterprises to seek 
opportunities and also to keep track of changes in the market and customer preferences.

Research highlights that skills, knowledge and competencies of employees are of utmost importance for SMEs if they want to acquire new technologies and knowledge for their survival (Hashim, 2012; Saleh, et al. 2008). İt has been further highlighted that due to limited capacities of SMEs, they are less innovative as compared to their counterparts in other countries (Hashim, 2012). However, the results of the study contradict this point. The employees are found to be knowledgeable and innovative in nature, however, their competency levels have been found to be at low, which is translated into insignificant result for competence, agility and skills. Researchers are of the view that organizational sustainability stems from the organization's capability to create sustainable value and its intellectual capital including trust, loyalty, honesty and satisfactory stakeholder relations (Bounfour \& Edvinsson, 2005; Ciasulli \& Troisi, 2013; Edvinsson, 1997). The value and quality can be attributed to quality of employees' an organization has. Furthermore, the knowledge, values, skills and experiences of employees have significant impacts on social and environmental sustainability of SMEs and this intellectual capital can be used to attain competitive advantage for promoting innovations regarding social and environmental practices and keeping themselves ahead of competitors (Loucks, et al. 2010).

\section{Conclusion}

The study investigated the role of intellectual capital towards sustainability of SMEs. The results of the study are significant for the management of SMEs as well as for the policy makers especially for Malaysian policy makers. Malaysian policy makers are emphasizing more and more on the development of SMEs for economic and social development. The results of the study signify the importance of intellectual capital and its dimensions related to knowledge, innovativeness, competence, agility and skills of the employees. Previous researches have also highlighted the roles of these factors of intellectual capital towards attaining sustainability. Enhancing the knowledge, competencies, and skills of the employees not only helps in organizational innovations that is of utmost importance in attaining competitive advantage but also helps employees becoming more agile in nature. Intellectual agility which has been found insignificant in the study is important for employees as it helps them to adapt to the changing business environment and customer needs. Existence of capable and competent human resources in the organization helps in attaining organizational objectives. SMEs due to smaller size and resources should focus more on developing the intellectual capabilities of their staff. These capabilities are not only concerned with knowledge and information that exist in the environment and which should be translated into meaningful actions but are also concerned with the skills and competencies of the individuals that can be utilized by the smaller organizations and translated into competitive advantage and sustainability.

To gain useful insights as to how SMEs utilize their employees an in-depth study using mix methodology should be conducted. This would provide quite useful information regarding the SMEs and their mindset. Furthermore, a comparative study between service and manufacturing sector can also be done, which can provide insights regarding which sectors 
are more prone to utilizing the skills and competencies of their employees for attaining sustainability. To enhance the skills and capabilities of existing employees, organizations need to train their employees. For the purpose, role of on-the-job training and off-the-job training is crucial. Thus, future studies can also look at the role of educational institutions and their programs in developing the capabilities of the SME employees. Educational institutions especially higher education institutions are important because of their programs that supply skilled human resources to the market. Creating a linkage with these institutions can not only help smaller organizations but can also help in the entrepreneurial efforts of these educational institutions.

\section{References}

Aas, T. H., \& Pedersen, P. E. (2011). The Impact of Service Innovation on Firm-level Financial Performance. The Service Industries Journal, 31(13), 2071-2090. http://dx.doi.org/10.1080/02642069.2010.503883

Aldaba, R. M., \& Aldaba, F. T. (2010). Assessing the Spillover Effects of FDI to the Philipines. Makati City, Philippines: Philipine Institute for Development Studies.

Aris, N. M. (2006). SMEs: Building Blocks for Economic Growth. Paper presented at the National Statistics Conference.

Bartholomew, D. (2008). Building on Knowlegde: Developing Expertise, Creativity \& Intellectual Capital in the Construction Professions. Sussex: Wiley-Blackwell. http://dx.doi.org/10.1002/9781444301403

Bennet, A., \& Bennet, D. (2004). Organizational Survival in the New World: The Intelligent Complex Adaptive System. Burlington, MA: Butterworth-Heinemann.

Bennet, A., \& Bennet, D. (2010). Multidimensionality: Building the Mind/Brain Infrastructure for the Next Generation Knowledge Worker. On The Horizon, 18(3), 240-254. http://dx.doi.org/10.1108/10748121011072690

Bontis, N. (2001). Assessing Knowledge Assets: A Review of The Models Used To Measure Intellectual Capital. International Journal of Management Reviews, 3(1), 41-60. http://dx.doi.org/10.1111/1468-2370.00053

Bounfour, A., \& Edvinsson, L. (2005). Intellectual Capital for Communities: Nations, Regions, and Cities. Burlington, UK: Butterworth-Heinemann.

Bramley, G., \& Power, S. (2009). Urban Form and Social Sustainability: The Role of Density and Housing type. Environmental and Planning B: Planning and Design, 36(1), 30-48. http://dx.doi.org/10.1068/b33129

Choi, S., \& Ng, A. (2011). Environmental and Economic Dimensions of Sustainability and Price Effects on Consumer Responses. Journal of Business Ethics, 104(2), 269-282. http://dx.doi.org/10.1007/s10551-011-0908-8

Ciasullo, M. V., \& Troisi, O. (2013). Sustainable Value Creation in SMEs: A Case Study. The 
TQM Journal, 25(1), 44-61. http://dx.doi.org/10.1108/17542731311286423

Cook, R., Campbell, D., \& Kelly, C. (2012). Survival Rates of New Firms: An Exploratory Study. Small Business Institute ${ }^{\circledR}$ Journal, 8(2), 35-42.

Dyllick, T., \& Hockerts, K. (2002). Beyond the Business case for Corporate Sustainability. Business Strategy and the Environment, 11(2), 130-141. http://dx.doi.org/10.1002/bse.323

Dzinkowski, R. (2000). The Measurement and Management of Intellectual Capital: An Introduction. Management Accounting, 78(2), 32-36.

Edvinsson, L. (1997). Developing Intellectual Capital at Skandia. Long Range Planning, 30(3), 366-373. http://dx.doi.org/10.1016/S0024-6301(97)90248-X

Fritsch, M., \& Noseleit, F. (2013). Start-ups, long-and short-term survivors, and their contribution to employment growth. Journal of Evolutionary Economics, 23(4), 719-733. http://dx.doi.org/10.1007/s00191-012-0301-5

Goh, K. C., Seow, T. W., \& Goh, H. H. (2013). Promoting Sustainable Concept in Malaysian Housing Industry. Paper presented at the Sustainable Built Environment for Now and the Future, Hanoi, Vietnam, 26-27 March.

Grajkowska, A. (2011). Valuing Intellectual Capital of Innovative Start-ups. Journal of Intellectual Capital, 12(2), 179-201. http://dx.doi.org/10.1108/14691931111123386

Haltiwanger, J., Jarmin, R. S., \& Miranda, J. (2013). Who creates jobs? Small versus large versus young. Review of Economics and Statistics, 95(2), 347-361. http://dx.doi.org/10.1162/REST_a_00288

Hashim, F. (2012). Challenges for the Internationalization of SMEs and the Role of Government: The Case of Malaysia. Journal of International Business and Economy, 13(1), 97-122.

Hoq, M. Z., Ha, N. C., \& Said, S. M. (2009). SMEs in the Malaysian Economy. International Journal of Marketing Studies, 1(2), 3-17. http://dx.doi.org/10.5539/ijms.v1n2p3

Hutchins, M. J., \& Sutherland, J. W. (2008). An Exploration of Measures of Social Sustainability and Their Application to Supply Chain Decisions. Journal of Cleaner Production, 16(15), 1688-1698. http://dx.doi.org/10.1016/j.jclepro.2008.06.001

Jackson, W. (1980). New Roots for Agriculture. Berkeley, California: North Point Press.

Karchegani, M. R., Sofian, S., \& Amin, S. M. (2013). The Relationship Between Intellectual Capital and Innovation: A Review. International Journal of Business and Management Studies, 2(1), 561-581.

Kee-Luen, W., Thiam-Yong, K., \& Seng-Fook, O. (2013). Strategic Planning and Business Performance: A Study of SMEs in Malaysia. Paper presented at the 3rd Asia-Pacific Business Research Conference, 25-26 February, Kuala Lumpur, Malaysia.

Koe, W.-L., \& Majid, I. A. (2013). Sustainable Entrepreneurship among Small and Medium 
Enterprises (SMEs) in Malaysia. International Journal of Economics, Finance and Management, 2(4), 286-290.

Kramer, J.-P., Marinelli, E., Iammarino, S., \& Diez, J. R. (2011). Intangible Assets as Drivers of Innovation: Empirical Evidence on Multinational Enterprises in German and UK Regional $\begin{array}{llll}\text { Systems of Innovation. Technovation, 31(9), 47-458. } & \text {. }\end{array}$ http://dx.doi.org/10.1016/j.technovation.2011.06.005

Kuratko, D., \& Hodgetts, R. (2004). Entrepreneurship: Theory, Process and Practice. 2004. Mason, Ohio: Thomson.

Leaniz, P. M. G. d., \& Bosque, I. R. d. (2013). Intellectual Capital and Relational Capital: The Role of Sustainability in Developing Corporate Reputation. Intangible Capital, 9(1), 262-280.

Lipsey, R. E., \& Sjoholm, F. (2005). The Impact of Inward FDI on Host Countries: Why Such Different Answers? Does Foreign Direct Investment Promote Development (pp. 23-43). Washington DC: Institute for International Economics and Center for Global Development.

Longenecker, J. G., \& Moore, C. W. (2006). Small Business Management: An Entrepreneurial Emphasis: Thomson/South-Western.

Loucks, E. S., Martens, M. L., \& Cho, C. H. (2010). Engaging Small and Medium Sized Busineses in Sustainability. Sustainability Accounting Management and Policy Journal, 1(2), 178-200. http://dx.doi.org/10.1108/20408021011089239

Martinez-Fernandez, C., \& Choi, K. (2013). Skills Development Pathways in Asia. In R. Maclean, S. Jagannathan \& J. Sarvi (Eds.), Skills Development for Inclusive and Sustainable Growth in Developing Asia-Pacific (Vol. 19). New York: Asian Development Bank. http://dx.doi.org/10.1007/978-94-007-5937-4_9

McGrath, R., \& Sparks, W. (2006). Knowledge, Social Capital and Organizational Learning. International Journal of the Management, 5(9), 125-129.

Mohr, L. A., \& Webb, D. J. (2005). The Effects of Corporate Social Responsibility and Price on Consumer Responses. The Journal of Consumer Affairs, 39(1), 121-147. http://dx.doi.org/10.1111/j.1745-6606.2005.00006.x

Moore, L., \& Craig, L. (2008). Intellectual Capital in Enterprise Success: Strategy Revisited. New Jersey: John Wiley \& Sons.

Murphy, P. R., Poist, R. F., \& Braunschweig, C. D. (1995). Role and Relevance of Logistics to Corporate Environmentalism: An Empirical Assessment. International Journal of Physical Distribution \& Logistics Management, $\quad$ 25(2), 5-19. http://dx.doi.org/10.1108/09600039510083916

Nahapiet, J., \& Ghoshal, S. (1998). Social Capital, Intellectual Capital, and the Organizational Advantage. The Academy of Management Review, 23(2), 242-266.

Obasan, K. (2012). The Impact of Human Resource Management on Small Business 
Performance in Nigeria: An Emperical Juxtaposition. International Journal of Business and Management Tomorrow, 2(2), 1-6.

Papagiannidis, S., Li, F., Erkowitz, H., \& Clouse, M. (2009). Entrepreneurial Networks: A Triple Helix Approach for Brokering Human and Social Capital. Journal of International Entrepreneurship, 7(3), 215-235. http://dx.doi.org/10.1007/s10843-009-0038-x

Rosenbusch, N., Brinckmann, J., \& Bausch, A. (2011). Is Innovation Always Beneficial? A Meta-analysis of the Relationship Between Innovation and Performance in SMEs. Journal of Business Venturing, 26(4), 441-457. http://dx.doi.org/10.1016/j.jbusvent.2009.12.002

Rosli, M. M. (2012). Competitive Strategy of Malaysian Small and Medium Enterprises: An Exploratory Investigation. American International Journal of Contemporary Research, 2(1), 93-105.

Saleh, A. S., Caputi, P., \& Harvie, C. (2008, 2-3 August). Perceptions of Business Challenges Facing Malaysian SMEs: Some Preliminary Results. Paper presented at the 5th International Conference on SMEs in Global Economy, Tokyo, Japan.

Schaper, M. (2002). The Challenge of Environmental Responsibility and Sustainable Development: Implications for SME and Entrepreneurship Academics Radical Changes in the World: Will SMEs Soar or Crash (pp. 541-553).

Seuring, S., \& Muller, M. (2008). From a Literature Review to a Conceptual Framework for Sustainable Supply Chain Management. Sustainability and Supply Chain Management, 16(15), 1699-1710.

Shane, S. (2012). Small Business Failure Rates by Industry: The Real Numbers. from http://smallbiztrends.com/2012/09/failure-rates-by-sector-the-real-numbers.html

Sheth, J. N., Sethia, N. K., \& Srinivas, S. (2011). Mindful Consumption: A Customer-Centric Approach to Sustainability. Journal of the Academy of Marketing Science, 39(1), 21-39. http://dx.doi.org/10.1007/s11747-010-0216-3

Sidek, A. A., \& Backhouse, C. (2014). Environmental Sustainability Issues in Malaysian Metal and Fabrication SMEs: Comparative Analysis from a Case Study Perspective. Paper presented at the International Conference on Industrial Engineering and Operations Management, January $7-9,2014$.

SMEAR. (2012). SME Annual Report 2011-12. Kuala Lumpur: National SME Development Council.

SMECorp. (2013). SME Masterplan: Catalysing Growth and Income. Kuala Lumpur, Malaysia: National SME Development Council.

Spahic, E., \& Huruz, E. (2012). Improving the Management of Intellectual Capital Through the Application of Organizational Learning. Paper presented at the 4th European Conference on Intellectual Capital: ECIC 2012, 23-24 April, Helsinki, Finland.

Suyanto, R. A. S., \& Bloch, H. (2009). Does Foreign Direct Investment Lead to Productivity 
Spillovers? Firm Level Evidence from Indonesia. World Development, 37(12), 1861-1876.

Topal, Y., Conkar, M. K., \& Mustafa, U. C. (2008, 28-29 March). The Constitution and Measurement of Intellectual Capital: An Application in Banking Sector in Afyonkarahisar. Paper presented at the First International Conference on Management and Economics, Epoka University, Turkey.

UNESCAP. (2013). Asia-Pacific Trade and Investment Report 2013: Turning the Tide: Towards Inclusive Trade and Investment. New York: United Nations Economic and Social Commission for Asia and The Pacific.

Wall, A., Kirk, R., \& Martin, G. (2004). Intellectual Capital: Measuring the Immeasurable. Amsterdam: CIMA Publishing.

Wang, Z., \& Wang, N. (2012). Knowledge Sharing, Innovation and Firm Performance. Expert Systems with Applications, 39(10), 8899-8908. http://dx.doi.org/10.1016/j.eswa.2012.02.017

WECD. (1987). Our Common Future. New York: United Nations World Commission on Environment and Development.

Yacob, P., Aziz, N. S. B., Makmor, M. F. b. M., \& Zin, A. W. b. M. (2013). The Policies and Green Practices of Malaysian SMEs. Global Business and Economics Research Journal, 2(2), $52-74$.

Zimmerer, T., Searborough, N., \& Wilson, D. (2008). Essential of entrepreneur1/2ship and small business management: New Jersey: Prentice Hall, Upper Saddle River.

\section{Copyright Disclaimer}

Copyright for this article is retained by the author(s), with first publication rights granted to the journal.

This is an open-access article distributed under the terms and conditions of the Creative Commons Attribution license (http://creativecommons.org/licenses/by/3.0/). 